\title{
Is 'Happiness' Required in Curriculum? Impact on the Psychological Wellbeing of the Learner
}

\author{
Divya Tahira Mayadas
}

\begin{abstract}
The environment in which children grow up today is unpredictable, with constantly changing social and economic dynamics, making it difficult to predict what the future in which children of tomorrow will live and work turn out to be like. India has arrived at a stage of alarming suicide rates among students(Kumar, et al., 2013). Individuals come to educational institutes with myriad stressors arising from numerous sources, including familysystem disturbances, peer-interaction conflicts, sociocultural components, and vulnerabilities to physical and mental health risk factors. Research revealed 26 suicides reported every 24 hours due to issues including drugs, broken families, fights with friends and breakups. Prolonged exposure to such stressors leads to long term physiological and emotional disturbances, which severely hinders an individual's learning \& development. Lack of trust, insecurity, impulsivity, social comparisons, over achievements, lack of sense of identity and low self-esteem can lead to skewed, imbalanced growth, the repercussions of which could be dreadful and far-reaching. As per the World Happiness Report 2017, India is sadly among the world's least happy nations. India ranked 122 among 155 countries in the global ranking, and further slipped to 133 among 155 countries in the World Happiness Report of 2018. This poses a significant challenge for society and families on how individuals should be nurtured and prepared. This compels us to re-think the purpose of education more than merely improving the student's scholastic performance. We need to analyse how happy are children within these systems? This question requires us to consider the critical linkage between happiness and our current education system (UNESCO, 2016).
\end{abstract}

Index Terms- Happiness Index,Economic Development, Education Institutes, Management

\section{INTRODUCTION}

Curriculum of the current times has seen numerous changes, before it reached to where it is now. Compared to the earlier times, the learners of the today have a lot more on their plate as the future is unpredictable. Many of them have had to tackle rigorous schedules, numerous co curriculars and at the same time manage to perform their best. At the same time, this trains them to multitask and develop the skill of time management, over and above excelling in their chosen field of study(Mogilner, et al., 2012).

Divya Tahira Mayadas, Faculty of Economics, Chatrabhuj Narsee School, Mumbai, India
In the scheme of things, the main focus is excellence, and the drive to do better than not just their personal best, but also be the best among peers. This puts a lot of pressure of performance and competition, which may not be the best for the mental health of the individual, as it is the perfect brew for anxiety, stress and mental and physical exhaustion. This paper aims to explore the benefit of having a dedicated session of 'happiness' training for learners, where the focus is not on competition and being the best, but rather on the mental wellbeing, calming the mind and exploring what brings joy to the individual(Inglehart, et al., 2008). This will be meaningful and impactful with respect to the holistic development of the mind. It will allow the individual to break the fetters of anxiety and competition, learner to focus on what centres them, allows them mental peace and overall helps them to have a 'happy' experience, rather than one fraught with competitive targets and constant comparisons among peers.

\section{OBJECTIVE}

The objective of the paper is to determine the impact of 'happiness' on the overall development of the learner, over and above the importance of standard subject areas covered. The paper will explore the need of this in today's day, and importance of incorporating 'happiness' in the curriculum of schools. It is important to establish how the same will be beneficial for the overall holistic development of learners. These learners are the future of the nation; its valuable human capital.

\section{METHODOLOGY}

The research paper is reliant on external secondary data research. The paper aims to discern the true challenges faced by educational institutes during the coronavirus pandemic. In order to do the above the research study has explored various government statistics, institution wise statistics and published research work of a similar nature. Having done so, the paper brings to the fore ways and means by which the education industry of India is trying to cope with the pandemic, and the innovative techniques thus used.

\section{PSYCHOLOGICAL WELLBEING}

Let us understand what we mean by the concept of happiness, which needs to be incorporated in the curriculum. Happiness is something the management more often than not assumes to be the natural byproduct of the ordinary curriculum being followed. The system of 


\section{Is 'Happiness' Required in Curriculum? Impact on The Psychological Wellbeing of The Learner}

the institutions caters to extra curriculars and numerous activities which can be pursued by the learners(Pykett, 2018). But the bottom line is that 'happiness' is assumed to be an innate quality to the current system followed. But it may not be so with every learner in the system. Some learners require additional help and guidance for achieving the same. Such learners need handholding in the process of achieving mental wellbeing(Davanti Counsellor, 2018). Mental wellbeing is of paramount importance, especially in the highly stressful and volatile times of today. Having a dedicated session with qualified mentors and guides will help to alleviate the mental burden the learners face nowadays.

The consequence of challenging situations may be any or all of the three; anxiety, stress and depression. They are not one and the same thing, although they are oftentimes used interchangeably; they all have distinct differences, which are important to identify and take not of(Putwain, 2007). Anxiety is where the individual suffers constantly from a nagging worry and suffers from sudden clear or unclear triggersand if this is not treated it can affect the individual's ability to work, study or even maintain relationships (Blundell \& Lambert, 2014). It is imperative to take help of a professional mentor or coach who will be able to suggest the best possible treatment of the same. Mental health issues have no age barrier, and can affect anyone, irrespective of their age, gender, nationality or any such label, and therefore there should be no stigma attached to have professional help to deal with mental health issues (Eisenberg, et al., 2007). Depression too is a mental health issue, where the individual required professional intervention, as it affects the way the individual functions, interacts with friends and family, the way the work and their outlook to life(Kieling, et al., 2019). This mental illness is one which most certainly required external help, as it is difficult to cure it singlehandedly. Although the general symptoms of depression are sadness, hopelessness, anger, lack of interest in life, low energy, insomnia and overwhelmed by personal interactions, there may be those who are highly social and seem happy, yet are depressed(Leonard, 2019). In fact, very often, those who are diagnosed with depression are diagnosed with anxiety as well.

Stress and anxiety can be confused one for the other, but in reality, they are not the same. Stress is a response to a threatening situation or the pressures of daily tasks and deadlines. Stress has physical manifestations in the individual, and affect their physiological wellbeing, along with causing mental exhaustion(Felman, 2020). Stress can cause headaches, nausea, high blood pressure, chest pain, heart palpitations and loss of sleep. Generally, stress goes away when the triggers go away. But if there is chronic stress, them it may snowball into anxiety or depression. For learners of today, there are numerous stressors that may affect their mental wellbeing, such as the coronavirus pandemic, demise of friends and family, cancellation of examinations, further studies entrances, postponement of tertiary institutes reopening, skyrocketing competition, changing visa policy of countries, discrimination and decision regarding future plans, just to name a few(Bouskill \& Smith, 2019). These can be very overwhelming, and having help to navigate through this quagmire of worry is essential for their mental health.

\section{IMPORTANCE OF 'HAPPINESS' IN CURRICULUM}

Anxiety and stress wreak havoc on the individual, and more often than not, external intervention is needed. To prevent things from souring, its highly beneficial to have focused sessions of 'happiness' in the curriculum, where the individual can openly discuss what troubles them. The mentors can aid them as to how to navigate through the anxiety and center themselves(Frey \& Stutzer, 2002). The professionals will be able to guide the individuals on what brings them joy, what can they do to tackle stressful situations, how to incorporate mindfulness in their daily life and the benefits of the same. Mindfulness and meditation allow the individual to keep the mind healthy, as with a healthy mind, there will be a strong focus and also the individual will be mentally strong(Jennings, et al., 2011). Keeping feelings of anxiety bottled by is detrimental; individuals should be encouraged to have open communication with family, friends and their dedicated mentors, so that those close to them can detect any red flags, and help the individual tackle the situation wisely(Moran, 2015). Hence, it is crucial for institutes to have professionals who have dedicated sessions with the learners, so that over multiple interactions they may be able to identify if any of the individuals are suffering from any such mental health issue, or if anyone is susceptible to develop the same(Halperin, 1987).

Mahatma Gandhi said, "By education, I mean an allround drawing of the best in child and man in body, mind and spirit". The primary purpose of education has to be to incorporate technology to modernize learning, and at the same time create happy, confident and fulfilled human beings who will play a meaningful role in society(Buchanan, 2013). Whatever we do is for the sake of happiness, as happiness is the greatest human expression, and it is safe to say that the prime aim of humans is to achieve happiness in their lives. Across the world, education administrators are realizing the need for a happiness or well-being lesson for children, with selfaware, sensitive and emotionally mature children being far more successful owing to their advanced ability to engage in meaningful relationships(Frank, 2019). Numerous researches suggest that the primary purpose of education is to create confident, mindful, responsible and happy individuals who collectively build a happy and harmonious society. In today's world all of us are striving hard to attain happiness and everything we do in life is just a presumed step towards happiness(Hopkins, 2017).

The Delhi government with an aim to train the young minds to make them happy, confident and content human beings and for developing their personality has launched 'Happiness curriculum' in schools(Directorate of Education, 2019). Over 1,000 Delhi government schools 
have incorporated the new curriculum in their system, between Nursery and Class 8 . The students will have a 'Happiness' period which will be for a duration of fortyfive minutes(Directorate of Education, 2019). The new curriculum is based on learner-centric education which incorporates a considerable amount of meditation, value education and mental exercises. The entire curriculum will be purely hands on learning and activity-based with no formal examinations conducted on it(Directorate of Education, 2019). However, a periodic assessment of children's progress will be made using a happiness index. With increasing pressure on students from both parents and teachers to score more marks, this inventiveness of the Government is expected to help the students to cope up with stress and learn for life, not for just a rank(Hartfiel, et al., 2011). This resonates the spirit of Mahatma Gandhi's quote "Literary education is of no value, if it is not able to build up a sound character". Education cannot be seen in isolation from the dire needs of today's society, rather it serves a larger purpose to nurture the human capital of the future (Boniwell \& Ryan, 2012). Educators and schools across the globe are realizing the need for a wellness lesson for school children. It is also observed that self-aware, sensitive and emotionally mature children are far more successful in life owing to their ability to manage stress, anxiety, trust and relationships with their family and friends(Nagraj, 2015). Education thus will have to ensure it meets society's need with changing time and space be it moral, societal or even character building.

\section{CONCLUSION}

But it is also true that even after educating millions of young people every year, we are not able to provide an assurance that an educated person can live a life rising above the evils of violence, animosity, greed, malice. Today, the greatest challenges facing humankind are to deal with conditions that are arising due to societal evils.Children spend approximately twenty years within the education system until they graduate, during which time, we are successful in making them good engineers, doctors, scientists, managers or other professionals, but do not ensure that they become honest and responsible human beings. The Happiness Curriculum is a crucial step in this direction, as with this we will be able to make the education system an enabler for the all-round development of humankind and human capital of the future (Angier, 2020). When an individual learns to be satisfied, confident and above everything, happy with oneself and their achievements, stress levels will reduce automatically and one will develop a deeper insight not only of themselves, but also of others, and learn to handle stressful situations more adeptly (Hurt, 2019). Consequently, a happy being with deeper insight tends to have greater inclination for self-discovery and lower selfdeception. Against this backdrop, the need to raise and prepare future citizens who are mindful, aware, awakened, empathetic, firmly rooted in their identity with wings that can help them thrive in this uncertain world seems to be necessary, now more than ever before.

\section{REFERENCES}

[1] Angier, T., 2020. Happiness as Subjective Well-Being: An Aristotelian Critique. Revista Portuguesa de Filosofia, 76(1), pp. 149180 .

[2] Blundell, S. \& Lambert, F., 2014. Information Anxiety from the Undergraduate Student Perspective: A Pilot Study of Second-semester Freshmen. Journal of Education for Library and Information Science, 55(4), pp. 261-273.

[3] Boniwell, I. \& Ryan, L., 2012. Personal well-being lessons for secondary schools: Positive psychology in action for 11 to 14 year olds, Maidenhead: Open University Press.

[4] Bouskill, K. E. \& Smith, E., 2019. Global Health and Security: Threats and Opportunities, s.l.: RAND Corporation.

[5] Buchanan, W., 2013. ASEE TODAY. ASEE Prism, 22(9), pp. 61$63,65-74,76$.

[6] Davanti Counsellor, 2018. Davanti Counsellor. [Online] Available at: https://davanticounselling.com/2018/10/08/how-mentoring-canboost-mental-health/ [Accessed 10 July 2020].

[7] Directorate of Education, 2019. Happiness Curriculum, New Delhi: State Council of Educational Research and Training.

[8] Eisenberg, D., Golberstein, E. \& Gollust, S. E., 2007. Help-Seeking and Access to Mental Health Care in a University Student Population. Medical Care, 45(7), pp. 594-601.

[9] Felman, A., 2020. Medical News Today. [Online] Available at: https://www.medicalnewstoday.com/articles/145855 [Accessed 10 July 2020].

[10] Frank, J., 2019. REFLECTIONS ON THE LIBERAL EDUCATION. In: Being a Presence for Students: Teaching as a Lived Defense of Liberal Education. s.l.:Lever Press, p. 33-40.

[11] Frey, B. S. \& Stutzer, A., 2002. What Can Economists Learn from Happiness Research?. Journal of Economic Literature, 40(2), pp. 402435 .

[12] Halperin, D., 1987. THE SELF-HELP GROUP: THE MENTAL HEALTH PROFESSIONAL'S ROLE. Group, 11(1), pp. 47-53.

[13] Hartfiel, N. et al., 2011. The effectiveness of yoga for the improvement of well-being and resilience to stress in the workplace. Scandinavian Journal of Work, Environment \& Health, 37(1), pp. 70-76.

[14] Hopkins, E. A., 2017. John Dewey and Progressive Education. The Journal of Educational Thought, 50(1), pp. 59-68.

[15] Hurt, S., 2019. URBANIZATION \& MENTAL HEALTH: A LOOK AT THE DEVELOPING WORLD. Harvard International Review, 40(1), pp. 24-29.

[16] Inglehart, R., Foa, R., Peterson, C. \& Welzel, C., 2008. Development, Freedom, and Rising Happiness: A Global Perspective (1981-2007). Perspectives on Psychological Science, 3(4), pp. 264-285.

[17] Jennings, P. A., Snowberg, K. E., Coccia, M. A. \& Greenberg, M. T., 2011. Improving Classroom Learning Environments by Cultivating Awareness and Resilience in Education (CARE): Results of Two Pilot Studies. The Journal of Classroom Interaction, 46(1), pp. 37-48.

[18] Kieling, C. et al., 2019. Identifying depression early in adolescence. The Lancet Child \& Adolescent Health, 3(4), pp. 211-213.

[19] Kumar, S., Bhattacharya, S., Verma, A. K. \& Rathore, S., 2013. Trends in Rates and Methods of Suicide in India. Egyptian Journal of Forensic Sciences, 3(3), pp. 75-80.

[20] Leonard, J., 2019. Medical News Today. [Online] Available at: https://www.medicalnewstoday.com/articles/325513 [Accessed 10 July 2020]. 
[21] Mogilner, C., Aaker, J. \& Kamvar, S. D., 2012. How Happiness Affects Choice. Journal of Consumer Research, 39(2), pp. 429-443.

[22] Moran, K., 2015. Anxiety in the classroom: Implications for middle school teachers. Middle School Journal, 47(1), pp. 27-32.

[23] Nagraj, A., 2015. Philosophy of Human Behaviour. Jeevan Vidya Prakashan.

[24] Putwain, D., 2007. Researching Academic Stress and Anxiety in Students: Some Methodological Considerations. British Educational Research Journal, 33(2), pp. 207-219.

[25] Pykett, J., 2018. The Conversation. [Online] Available at: https://theconversation.com/happiness-is-the-metric-of-the-future-butthere-are-problems-with-how-we-measure-it-102611[Accessed 10 July 2020].

[26] UNESCO, 2016. Happy Schools! A Framework for Learner WellBeing in the Asia Pacific, Bangkok: United Nations Educational, Scientific and Cultural Organization.
Divya Tahira Mayadas: Ms. Mayadas is a faculty of Economics in the Chatrabhuj Narsee School, in Mumbai, Maharashtra, India. She teaches standards 9,10 and 11. Ms. Mayadas was a visiting faculty in St. Xavier's College, Mumbai, as well. She has completed her Master's in Business Administration in Finance from Symbiosis Institute of Management Studies, with the final semester completed in Leeds Beckett University, Leeds, United Kingdom. Ms. Mayadas has done BA Economics, from St. Xavier's College, Mumbai, India, where she passed with distinction. She has published 'Challenges in Education Management Due to The Coronavirus Pandemic', in the research journal, International Journal of Advance Research, Ideas and Innovations in Technology (IJARIIT) (ISSN: 2454-132X), Volume 6, Issue 4, 11th July 2020 and 'Need of The Hour? Efficacy of Digital Marketing in India', in the research journal, The International Journal of Creative Research Thoughts (IJCRT) (ISSN: 2320-2882), Volume 8, Issue 6, June 2020.Ms. Mayadas has contributed to The Correspondent, via her article, 'Beyond the Electronic Connection', on $22^{\text {nd }}$ May 2020. During her voluntary work with The Government of Maharashtra's MahilaArthik Vikas Mahamandal (MAVIM) and Sahabhag Social Responsibility Cell, Divya Mayadas looked after the onboarding and provided technical handholding to the women entrepreneurs of three Community Managed Resource Centres (CMRC) located in the slums of Mumbai, namely, Dharavi slum's Tanishka CMRC, Kurla slum's GheBharari CMRC and Chandivali slum's Kshitij CMRC. Ms. Mayadas maintains a blog as well, where she pen's down her travel experience and photography, which can be found at: https://www.thetrouvaille.org/. 